\title{
Consumer Acceptance of an Electronic Dinar Payment System in Malaysia
}

\author{
Mohd-Nazri Muhayiddin ${ }^{1}$, Elsadig Musa Ahmed ${ }^{2}$ and Hishamuddin |smail ${ }^{2}$ \\ ${ }^{1}$ Faculty of Entrepreneurship \& Business, Universiti Malaysia Kelantan, Kelantan, Malaysia \\ ${ }^{2}$ Faculty of Business \& Law, Multimedia University, Melaka, Malaysia
}

\begin{abstract}
This study attempts to solve several problems associated with physical gold dinar when used as a form of payment. One dinar is equal to 4.25 gram of fine gold. Specifically, this work proposes the use of e-commerce technology -- known as electronic dinar payment system -- to solve those problems. But before actual system can be implemented, this research seeks to find out whether or not the public would be ready to adopt the concept of electronic dinar payment system. The research framework is based on Unified Theory of Acceptance and Use of Technology (UTAUT) (Venkatesh et al., 2003). It measures the user acceptance based on these constructs; performance expectancy, effort expectancy, social influence, and facilitating conditions. In addition, anxiety, perceived credibility, and attitude toward using are added as three new constructs. Data collection is based on a questionnaire survey. This paper presents descriptive analysis results whereby it is discovered that most of the respondents participated in this survey generally agree with the idea of using the proposed electronic dinar payment system (mean rating of above 4.00).
\end{abstract}

Keywords: Electronic Payment Systems, Inflation, Monetary Economics, Gold Dinar

\section{Introduction}

With the prices of gold and silver having hit a new "all-time" high in July 2011, our society has begun to take notice and thus started to ponder on the importance of the two precious metals (gold and silver). Barisheff (2006) has reported that the US dollar has lost $82 \%$ of its purchasing power, as measured by the Consumer Price Index (CPI) since 1971. He further illustrated that if 100 widgets can be bought with $\$ 1$ in 1971, only 18 of such widgets can be bought for $\$ 1$ in 2006 . Mathematics calculations will reveal something even more startling. Back then in 1971 the price of gold was \$35 per ounce (Lewis, 2007). At its highest price so far (14 July 2011), we need to fork out $\$ 1,592.50$ (Kitco Inc., 2011) to buy exactly the same one ounce of gold. Thus from 1971 to 2011 (in 40 years), in terms of US dollars, the inflation has gone up by $4450 \%$ i.e. $(1592.50-35) / 35$ x 100\%. Or equivalently, for the duration of 40 years, the US dollar has lost $4450 \%$ of its purchasing power. The strength of purchasing power in gold and silver has become known as facts by now and it is widely discussed in many literatures (Lewis, 2007; Meera, 2002; Turk and Rubino, 2004).

\section{Issues Related to Physical Dinar Coins}

But there is one obvious problem with gold (dinar) when compared to fiat currencies or paper money; it is physically heavier and thus difficult to be carried around for normal daily transactions. For instance, to carry around in one's pocket a 10 dinar (42.5 gram of gold) would be a reluctant experience for many people. Moreover, due to the softness (malleability) of the

Copyright (C) 2011 Mohd-Nazri Muhayiddin, Elsadig Musa Ahmed and Hishamuddin Ismail. This is an open access article distributed under the Creative Commons Attribution License unported 3.0, which permits unrestricted use, distribution, and reproduction in any medium, provided that original work is properly cited. Contact author: e-maill: mnazri@umk.edu.my 
precious metal, dinar will also be subjected to continuing "wear and tear" process if it was to be used repeatedly among the masses; whether it is done intentionally or otherwise. It was reported in Paarlberg (1993) that during the civilization of the Roman Empire, their ordinary citizens would clip the precious metal from the empire's coins perimeter in order to steal some of the value stored in the coins. He further wrote that slaves during that time "sweated" the coins by jiggling them in woolen bags hour after hour in order to wear-off some of the gold. The bags were then burned to separate the gold from the ashes. Another issue that needs to be addressed would be how to identify the purities of dinar denominations in each transaction such that fraud and cheating cases would be minimized and if possible, totally prevented. Mechanisms to facilitate or possibly bypass the unnecessary checking of purities for each transaction should be included in the electronic dinar payment system in order to make it realistically acceptable by users. The fourth issue is the divisibility constraint associated with dinar. In today's price, the value of 1 dinar is in the range of RM700RM750 a piece, thus making it impractical for buying of small-priced items. The dirham (silver) denomination is supposed to cater these small-priced transactions. Nevertheless if users insist on using the dinar still, then the proposed system must be able to cater those small-priced transactions in dinar. Last issue that needs addressing is the possible consumer losses due to the difference in selling and buying prices, which is known as "spread". In practice, the spread will be from $3 \%$ to $7 \%$ on average (for one dinar), charged by gold/dinar sellers to form a profit. In this case, it is not profitable for consumers to use the electronic dinar payment system immediately after buying it. This is because shop owners would only buy back the same dinar at the "buying price", which is always lower than the "selling price". Table 1 below illustrates this point:

Table 1: Customer Would Stand to Lose Out Due to the Practice of "Spread" by Shop Owners

\begin{tabular}{llll}
\hline Item & Selling price & Buying price & Spread \\
\hline 1 dinar & RM735 & RM700 & RM35 (or 5 \%) \\
& $>$ Initially, & > For payment, shop owners & $>$ Thus, if use immediately, \\
& customers buy & would only accept the same & customers will lose out \\
& dinar at this price. & dinar at this lower price. & $\begin{array}{l}\text { RM35 in value because of } \\
\text { this spread. }\end{array}$ \\
\hline
\end{tabular}

Obviously this "spread" issue needs to be solved or else it would be unprofitable and thus impractical for customers to use the electronic dinar payment system. Therefore, those issues of portability, wear and tear, purity concerns, divisibility and the dinar spread -- all of them must be properly addressed in order for gold dinar payment to be widely accepted by the public. In particular, this work would focus on using the e-commerce technology in a form of an electronic payment system to solve a few physical constraints associated with gold dinar. The reason to introduce the electronic commerce technology in dinar is because it offers several advantages that the (brick-and-mortar) physical dinar simply could not offer.

\section{Real Prices Based on Secondary Data}

In order to be as close to a practical situation as possible, this study uses actual data (from real Malaysian market) to show the superior performance of gold's purchasing power when compared to that of Ringgit Malaysia (RM). Prices of a few inflationary items are shown in RM together with their corresponding prices in dinar (gold). In this case, the price performance (purchasing power) between these two competing currencies can be compared side by side. The readers can therefore make a straight-forward comparison between fiat currency and sound money (dinar) in terms of their purchasing power performance. 
Tables 2 to 5 below illustrate the performance of dinar as compared to the performance of fiat currency (i.e. RM) for various critical consumer items and services. Table 6 shows salary comparison -- paid in dinar versus that paid in Ringgit Malaysia (RM). It is to be noted that oil and electricity prices are two inflationary items whereby any price increase in these two items will subsequently give rise to prices of other daily food items and services (Barisheff, 2006; Leeb and Strathy, 2006). Similarly, construction items will give subsequent price rise to constructionrelated markets such as commercial (office) and residential (house) buildings.
As for the case of salary, Table 6 clearly shows that dinar preserves the value of salaries over time. Apparently, salaries paid in dinar appreciate over time automatically, even without annual increments. It should be noticed from the tables above that the performance of dinar is much superior as compared to that of RM (or other fiat money). Apparently in all tables, what appears to be a "price increase (inflation)" in RM is simply a "price decrease" in dinar. It becomes obvious from the above tables that dinar (gold) is able to preserve their intrinsic value; whereas the paper (fiat) money simply could not do that.

Table 2: Fuel Price Comparison (RM and Dinar)

\begin{tabular}{lrr}
\hline Petrol (50 liter) & RM & Dinar \\
\hline 2000 & 60.00 & 0.428 \\
2009 & 90.00 & 0.178 \\
Price increase/decrease & $\mathbf{+ 5 0 \%}$ & $-\mathbf{5 8 \%}$ \\
\hline & $\mathbf{R M}$ & $\mathbf{D i n a r}$ \\
\hline Diesel (50 liter) & 35.50 & 0.253 \\
2000 & 85.00 & 0.168 \\
Price increase/decrease & $\mathbf{+ 1 3 9 \%}$ & $\mathbf{- 3 4 \%}$ \\
\hline
\end{tabular}

Note:

* Prices of gold are USD270 and USD1050 respectively per ounce in Oct. 2000 and Oct. 2009 (London fix).
* Prices of petrol are RM1.20 and RM1.80 respectively per liter in 2000 and 2009.

* Prices of diesel are RM0.71 and RM1.70 respectively per liter in 2000 and 2009.

Table 3: Electricity Price Comparison (RM and Dinar)

\begin{tabular}{lrr}
\hline Electricity (Domestic, 300kWh) & RM & Dinar \\
\hline 2000 & 69.40 & 0.495 \\
2009 & 72.50 & 0.233 \\
Price increase/decrease & $\mathbf{+ 4 \%}$ & $\mathbf{- 5 3 \%}$ \\
\hline & & \\
\hline Electricity (Commercial, 3000kWh) & $\mathbf{R M}$ & $\mathbf{D i n a r}$ \\
\hline 2000 & 864.00 & 6.163 \\
2009 & 969.00 & 3.114 \\
Price increase/decrease & $\mathbf{+ 1 2 \%}$ & $\mathbf{- 4 9 \%}$ \\
\hline
\end{tabular}

Note:

* Prices of gold are USD270 and USD1050 respectively per ounce in Oct. 2000 and Oct. 2009 (London fix). 
Table 4: Construction Items Price Comparison (RM and Dinar)

\begin{tabular}{lrr}
\hline Cement (2 bags@100 kg) & RM & Dinar \\
\hline 2005 & 25.00 & 0.115 \\
2007 & 29.00 & 0.090 \\
Price increase/decrease & $\mathbf{+ 1 6 \%}$ & $\mathbf{- 2 1 \%}$ \\
\hline Steel (1 ton) & $\mathbf{R M}$ & Dinar \\
\hline 2005 & 1800.00 & 8.254 \\
2007 & 2100.00 & 6.551 \\
Price increase/decrease & $\mathbf{+ 1 7 \%}$ & $\mathbf{- 2 1 \%}$ \\
\hline
\end{tabular}

Note:

Prices of gold are USD420 and USD690

respectively per ounce in 2005 and

2007 (London fix).

Table 5: Cost of Hajj in RM and Dinar

\begin{tabular}{lrr}
\hline Cost of Hajj (lowest package) & RM & Dinar \\
\hline 2002 & 13,500 & 93.53 \\
2009 & 19,990 & 39.53 \\
\hline Price increase/decrease & $\mathbf{+ 4 8 . 1 \%}$ & $\mathbf{- 5 7 . 7 \%}$ \\
\hline
\end{tabular}

Note:

Prices of gold are USD278 and USD1050

respectively per ounce in 2002 and

2009 (London fix).

* Cost of Hajj is based on the lowest THTS package as per stated in Tabung Haji

(TH) Annual Report.

(THTS: TH Travel \& Services)

Table 6: Salary Comparison in RM and Dinar

\begin{tabular}{lrr}
\hline Salary Paid (Malaysia) & Dinar & RM \\
\hline Jan 1992 & $\mathbf{1 5 . 5 0}$ & $* \mathbf{1 8 0 0}$ \\
Jan 2007 & 15.50 & 4968 \\
Feb 2009 & 15.50 & 6975 \\
Oct 2009 & 15.50 & 7838 \\
\hline
\end{tabular}

Note:

* Price of gold in Jan. 1992 is USD340 per ounce.

* Price of gold in Jan. 2007 is USD690 per ounce.

* Price of gold in Feb. 2009 is USD915 per ounce.

* Price of gold in Oct. 2009 is USD1050 per ounce.

*RM1800 is a starting salary for a fresh engineer in Malaysia in 1992.

(All gold prices are based on London fix price)
Research Framework Based on UTAUT Model

Understanding of technology acceptance models is very important in order to fully appreciate why one model is chosen over the other. Researchers are always confronted with choosing the most appropriate model for their particular research. Most of the times, they must "pick and choose" constructs among the various models that are available. Alternatively, they may choose one "favored model" and largely ignore the possible contributions from other models. Effort by Venkatesh et al. (2003) to solve this predicament is greatly welcomed among the information system (IS) research circles. His team has introduced and tested the new and unified 
model, known as Unified Theory of Acceptance and Use of Technology (UTAUT) which integrates the previous eight (8) models used in technology acceptance studies. Those eight models are: Theory of Reasoned Action (TRA), Technology Acceptance Model (TAM), Motivational Model (MM), Theory of Planned Behavior (TPB), a model which combines TAM and TPB (C-TAM-TPB), Model of PC Utilization (MPCU), Innovation Diffusion Theory (IDT), and Social Cognitive Theory (SCT).

With the objective of introducing a comprehensive model that considers all variables included in the previous eight prominent models, Venkatesh et al. (2003) developed a research to empirically compare and test each of the constructs in those models. Their research has found that the eight previous models were able to explain (between) 17 to 53 percent of the variance in user intentions to use information technology. Subsequently, a unified model (UTAUT) that integrates elements across the eight models are thereby formulated and empirically validated. Using UTAUT, it is found that the model had outperformed the previous eight individual models with adjusted $\mathrm{R}^{2}$ of 69 percent. Later, UTAUT was validated with data from two new organizations; it still gave very similar results (adjusted $\mathrm{R}^{2}$ of 70 percent). Having had this substantial improvement over its predecessors, UTAUT would thus provide a very useful tool in order to assess the likelihood acceptance factors of introducing a new technology.
Therefore, the research framework for this work is adapted from UTAUT with three additional constructs added. This study intends to find out the consumer acceptance of electronic dinar payment system based on the four original constructs of UTAUT model. Those constructs are performance expectancy, effort expectancy, social influence, and facilitating conditions. The three additional constructs, perceived credibility, anxiety, and attitude toward using, are hypothesized to be very relevant to this study and therefore their influence is expected to be significant in the proposed model. Anxiety is adapted from Compeau and Higgins (1995) as well as Venkatesh et al. (2003). Perceived credibility is adapted from Wang et al. (2003). Attitude toward using technology is adapted from Davis (1989), as well as Taylor and Todd (1995). This research also intends to find out how significant is the contributions of moderators in this case. Out of four moderators from the original UTAUT model, only three would be applied in this study. Those three moderators are gender, age, and experience while the fourth moderator (voluntariness of use) is not included since the proposed electronic dinar payment system would be purely voluntary in nature and therefore the purpose this 'fourth moderator' is irrelevant in this case. The constructs used in this research framework are explained in Table 7 below. Figure 1 illustrates the model of research framework used for this study. 
Table 7: Research Framework Core Constructs Used in This Research

\begin{tabular}{ll}
\hline Core Constructs & Definitions \\
\hline $\begin{array}{l}\text { Performance } \\
\text { Expectancy }\end{array}$ & $\begin{array}{l}\text { The perception that using electronic dinar payment system would } \\
\text { benefit users in terms of purchasing power, asset preservation, and } \\
\text { safe-haven capability. This construct is adapted from UTAUT model } \\
\text { (Venkatesh et al., 2003). }\end{array}$
\end{tabular}

Effort Expectancy It is defined as the ease of using electronic dinar payment system for purchasing. This construct is adapted from UTAUT model (Venkatesh et al., 2003).

Social Influence It is defined as the social factors (i.e. important persons) which influence users to adopt electronic dinar payment system. This construct is adapted from UTAUT model (Venkatesh et al., 2003).

Facilitating It is defined as the existence of external factors that could facilitate Conditions the usage of electronic dinar payment system (such as good ICT infrastructure, government initiatives and so on). This construct is adapted from UTAUT model (Venkatesh et al., 2003).

Anxiety

To measure the fear of the public in using electronic dinar payment system i.e. fear of password/card stolen and fear of price fluctuation, and fear of gold investment scam. This construct is adapted from Compeau and Higgins (1995) as well as from Venkatesh et al. (2003).

Perceived

To measure the data security and privacy, misuse of data, the safety Credibility of electronic dinar payment system. This construct is adapted from Wang et al. (2003).

Attitude toward Using
It is defined as a person's positive or negative feeling such as level of liking, enjoyment, joy, and pleasure to use a technology (Davis, 1989; Taylor and Todd, 1995). 


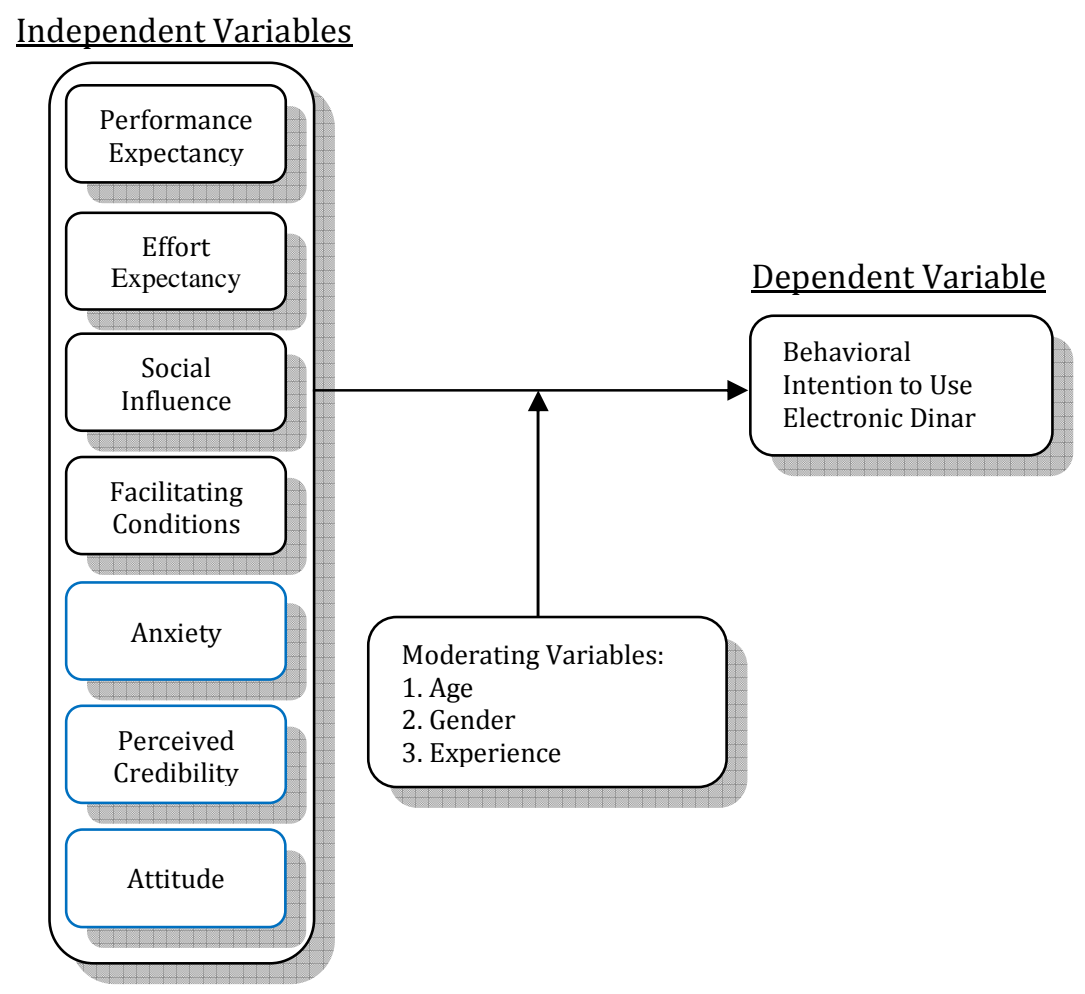

Figure 1: Research Framework for Consumer Acceptance of Electronic Dinar Payment System

\section{Methodology}

This research is a quantitative research whereby an analysis and classification of numerical data are collected from survey questionnaires. The questionnaires are developed based on research frameworks adapted from the Unified Theory of Acceptance and Use of Technology (UTAUT) model. Three new variables are added (anxiety, perceived credibility, and attitude toward using) to suitably reflect the individual technology acceptance of electronic dinar payment system. All questionnaires consist of closed-ended questions. Respondents only choose answers which have already been provided with the questions.

This paper investigates descriptive analysis results, of which the survey was distributed to 1000 respondents throughout Malaysia (Peninsula). The response rate was $87.2 \%$ (872 respondents had answered it completely). The first section of the survey contains questions related to respondents' experiences with e- commerce, gold, and dinar. Section A contains questions related to performance expectancy. Section B measures questions related to effort expectancy. Section C consits of questions related to social influence. Section D investigates questions related to facilitating conditions. Section E investigates factors related to anxiety (concerns) of adopting the proposed electronic dinar payment system. Section $\mathrm{F}$ measures perceived credibility (risk, security and privacy concerns). Section G contains four questions measuring respondents' attitude toward using the electronic dinar payment system. Section $\mathrm{H}$ contains three questions measuring respondents' behavioural intention to use the electronic dinar payment system. The last section of the survey consists of questions related to respondents' information such as gender, race, age, monthly income, educational attainment, marital status, and employment status. A five-point Likert scale is used to measure to what extent an individual agree or disagree to the questions being asked. Likert scale is measured as follows: ' 1 ' is for Strongly 
Disagree, '2' is for Disagree, ' 3 ' is for Neither agree nor disagree, '4' is for Agree, and ' 5 ' is for Strongly Agree. SPSS software has been used to carry out the descriptive analysis of the collected data.

\section{Results}

Table 8 shows the general profiles of the respondents participated in this study. About $58.1 \%$ of the respondents are male while the remaining $41.9 \%$ are coming from female respondents. In terms of age, most of the respondents are coming from young and middle age groups (25-39), which contributes to $75.7 \%$ of the total respondents. The other $6.8 \%$ is from $<24$ age group while another $17.5 \%$ is coming from $>40$ age group. of the total respondents, $51.8 \%$ has experience of buying (physical) dinar while the remaining $48.2 \%$ has no experience of buying it.

Table 8: Profiles of the Respondents

\begin{tabular}{llrr}
\hline & Items & Frequency & Percent \\
\hline Gender & Male & 507 & 58.1 \\
& Female & 365 & 41.9 \\
Age & Below 24 & & \\
& $25-39$ & 59 & 6.8 \\
& 40 and above & 660 & 75.7 \\
& & 153 & 17.5 \\
Experience (buying dinar) & Yes & 452 & 51.8 \\
& No & 420 & 48.2 \\
\hline
\end{tabular}


Table 9: Ratings of BI and Factors Affecting Respondents' Intention to Use

\begin{tabular}{|c|c|c|}
\hline Performance Expectancy & Mean & SD \\
\hline PE1: gold's appreciation & 4.12 & 0.661 \\
\hline PE2: gold's purchasing power & 4.08 & 0.636 \\
\hline PE3: protection against inflation & 4.14 & 0.678 \\
\hline PE4: protection during currency crisis & 4.13 & 0.670 \\
\hline PE5: accomplish payment quicker & 3.97 & 0.724 \\
\hline PE6: payment efficiency & 3.99 & 0.753 \\
\hline Effort Expectancy & Mean & SD \\
\hline EE1: easy to use & 4.07 & 0.545 \\
\hline EE2: easy to learn & 4.04 & 0.550 \\
\hline EE3: easy to interact & 4.02 & 0.575 \\
\hline EE4: compatibility & 3.99 & 0.632 \\
\hline EE5: convenience & 4.28 & 0.615 \\
\hline Facilitating Conditions & Mean & SD \\
\hline FC1: safe (to carry) & 4.24 & 0.593 \\
\hline FC2: safety (banks keep it) & 4.21 & 0.589 \\
\hline FC3: 'wear and tear' issue & 4.22 & 0.615 \\
\hline FC4: protected from rubbing, clipping & 4.20 & 0.650 \\
\hline FC5: purity issue & 4.14 & 0.753 \\
\hline FC6: divisibility issue & 4.14 & 0.755 \\
\hline Social Influence & Mean & SD \\
\hline SI1: people who influence & 3.88 & 0.601 \\
\hline SI2: people who are important & 3.89 & 0.630 \\
\hline SI3: family factor & 3.87 & 0.651 \\
\hline SI4: friends factor & 3.88 & 0.647 \\
\hline SI5: people who understand gold's value & 4.25 & 0.676 \\
\hline Perceived Credibility & Mean & SD \\
\hline PCR1: personal information & 4.08 & 0.808 \\
\hline PCR2: secured transactions & 4.12 & 0.703 \\
\hline PCR3: companies should be trustworthy & 4.50 & 0.659 \\
\hline PCR4: services owned by government & 4.18 & 0.882 \\
\hline PCR5: services operated by major banks & 4.33 & 0.697 \\
\hline PCR6: backed by physical dinar coins & 4.42 & 0.610 \\
\hline PCR7: physical dinar coins withdrawal allowed & 4.41 & 0.603 \\
\hline PCR7: widely accepted & 4.52 & 0.544 \\
\hline Anxiety & Mean & SD \\
\hline ANX1: gold investment scam & 4.05 & 0.975 \\
\hline ANX2: computer hacking & 4.11 & 0.862 \\
\hline ANX3: gold price fluctuation & 3.74 & 1.065 \\
\hline ANX4: losing card or password & 3.45 & 1.100 \\
\hline ANX5: lack of internet and computer skills & 1.87 & 1.203 \\
\hline Attitude Toward Using & Mean & SD \\
\hline \multirow{4}{*}{$\begin{array}{l}\text { ATT1: e-dinar is a good idea } \\
\text { ATT2: another option to make payment } \\
\text { ATT3: like to see use of dinar as payment } \\
\text { ATT4: interesting to use e-dinar }\end{array}$} & 4.15 & 0.534 \\
\hline & 4.13 & 0.509 \\
\hline & 4.15 & 0.554 \\
\hline & 4.20 & 0.555 \\
\hline Behavioral Intention to Use (BI) & Mean & SD \\
\hline BI1: intend to use & 4.07 & 0.547 \\
\hline $\mathrm{BI} 2$ : predict to use & 4.06 & 0.571 \\
\hline BI3: plan to use & 4.10 & 0.590 \\
\hline
\end{tabular}




\section{Discussion}

Overall, most of the respondents in this study would agree on the idea of using electronic dinar payment system. This is based on their ratings of behavioral intention to use which range from 4.06 to 4.10 (mean rating of 4.08) in Table 9 above. This is a positive result and consistent with the ratings of independent variables that are hypothesized to influence it. The ratings of those independent variables will be discussed next.

\section{Performance Expectancy}

It can be concluded that most of the respondents agree with the performance expectancy construct (Table 9) with its ratings range from 3.97 to 4.14 . These ratings are in agreement with the other studies on 'user acceptance' whereby it is found that perceived usefulness/performance expectancy has a positive effect on attitude toward using the mobile wallet (Shin, 2010) and on behavioral intention to use the Internet banking services (Yuen et al., 2010). The first four items with ratings greater than 4.00 show that most respondents agree with the advantage of electronic dinar in terms of appreciating values, purchasing power, inflation proof and "safe haven" capability. The last two factors in this construct carry slightly lower influence with ratings of only 3.99 and 3.97 . These last two factors show that some respondents are still unsure whether or not the system would be effective. This skepticism is understood since the actual electronic dinar payment system is yet to be launched and the experience of using the system is non-existent.

\section{Effort Expectancy}

Most of the respondents agree that if electronic dinar is similar to existing payment systems, it would be easy to use, learn, and interact (ratings of 3.99 to 4.07). This is in agreement with the other related research from Schierz, Schilke, and Wirtz (2010) which found that there is a positive relationship between perceived ease of use of mobile payment services and the attitude toward using the services. The 4.28 rating on the last factor in this construct (convenience) shows they would agree that using electronic dinar would be more convenient compared to using physical dinar coins.

\section{Facilitating Conditions}

This construct has scores of $>4.00$ in all of their factors (six of them). The range is from 4.14 to 4.24 . This result is in harmony with the other studies on user acceptance (Zhou, Lu, and Wang, 2010) which found that facilitating conditions has positively affected the user adoption of mobile banking services. Those factors that can facilitate the effective usage of electronic dinar payment system are explored in this construct. So it is not surprising, this construct carries high ratings. Most of the respondents agree with the fact that using electronic dinar is safer; it would protect the physical dinars from 'wear and tear' as well as from illegal rubbing and clipping issues. Apart from that, most of them also agree that using electronic dinar would solve problem with purity checking; as well as it could cater the buying of small-priced items. These salient features of electronic dinar are simply non-existent in brick-andmortar physical dinars. Please refer to Table 9 for other factors influencing this construct.

\section{Social Influence}

There appears to be a mixed reaction from respondents whether factors from this construct could influence their acceptance of electronic dinar payment system. Social influence or subjective norm is shown to have a positive effect on attitude toward use (Schierz, Schilke, and Wirtz, 2010) and on user's adoption in mobile banking (Zhou, Lu, and Wang, 2010). Ratings for the first four factors; 'people who influence', 'people who are important', family, and friends range from 3.87 to 3.89 . These ratings of $<4.00$ indicates that there are still some respondents who do not agree with the fact that 'social influence' will influence their usage of electronic dinar. 
However, most of them agree with the perception that those who understand the true value of gold would likely use electronic dinar payment system (rating 4.25).

\section{Perceived Credibility}

This is another construct which has scores $>4.00$ in all of their factors (ratings from 4.08 to 4.52). Trust (or perceived credibility) is shown to have a positive effect on attitude toward use (Ha and Stoel, 2009), on users' intention to use mobile wallet (Shin, 2010), and on consumers' use of e-payment system (Kim et al., 2010). The ratings indicate that most of the respondents agree that perceived credibility is an important construct, which will determine whether or not they intend to accept the electronic dinar payment system in the future. Several items have been rated highly by most of the respondents. Among them are 'companies that operate electronic dinar should be trustworthy', 'electronic dinar should be widely acceptable throughout Malaysia', 'electronic dinar should be $100 \%$ backed by physical dinars', and 'physical dinar coins withdrawal is allowed in electronic dinar payment system'.

\section{Anxiety}

Most of the respondents are certain that they would be afraid to use the proposed electronic dinar payment system due to the many cases of gold investment scam and also due to problems with hacking in computer/payment systems (ratings of 4.05 and 4.11 respectively). These results would agree with the other research on user acceptance which found that perceived risk (anxiety) decreases intention to transact in an online marketplace (Pavlou and Gefen, 2004). For factors 3 and 4 i.e. afraid of gold price going down and afraid of losing card or password, respondents are somewhat undecided in their opinions (mean $3.74 / \mathrm{SD}=1.065$ and mean $3.45 / \mathrm{SD}=1.100$ respectively). However, most of them disagree with factor 5 i.e. they are not afraid of lacking internet and computer skills (mean 1.87/SD=1.203). The standard deviation of $>1.000$ in factor 3,4 , and 5 indicate that respondents are significantly dispersed in opinion in these 3 cases.

\section{Attitude toward Using}

This construct has scores of $>4.00$ in all of their factors (four of them). The range is from 4.13 to 4.20 . This is in agreement with the other related research (Schierz, Schilke, and Wirtz, 2010; Shin, 2009; Yuen et al., 2010) which found that attitude toward using would have a positive relationship with intention to use. Most of the respondents agree that electronic dinar is a good and interesting idea. Most of them also agree that they would like to see dinar being used as a means of payment and most of them believe electronic dinar would give users another option to make payments.

\section{Recommendations and Further Research}

Banks or other institutions that are interested to offer e-dinar services to the public, should aggressively promote the service based on positive indications reflected from the constructs of performance expectancy, facilitating conditions, perceived credibility, and attitude toward using. Most of the factors in these four (4) constructs have ratings above 4.00 in the respondents' level of agreement. The service providers should really explain to potential consumers that e-dinar payment system would have strong advantages in terms of purchasing power, protection against inflation and protection (of assets) during any currency crises. Furthermore, the service providers should focus on highlighting the clear advantage of using e-dinar payment system compared to that of using a 'brick and mortar' (i.e. traditional) dinar payment system. Perceived credibility is another important aspect whereby in this case e-dinar service providers should develop the system that can be fully trusted by consumers. Ratings from perceived credibility construct indicate that in order to gain critical trust from the public, this e-dinar should be fully backed by physical dinar coins in their storage. Subsequently, withdrawal of those 
dinar coins should also be allowed. The service providers should also take note that this e-dinar service should be widely acceptable nationwide in order for it to be well-received by consumers. Last but not least, the service providers should really promote and convince the public that the idea of using e-dinar payment system is simply good and interesting.

Although this research only considers respondents from Malaysia, it could be replicated in other countries using similar research framework and instruments. Particularly, it should be done in the Arab regions whereby their countries have long been associated with the history of dinar usage previously. For other countries which may have not been familiar with the use of dinar, it is highly suggested for them to use gold (in gram) instead of dinar. So for the countries of the latter, the similar research should be done on electronic gold payment system instead of electronic dinar payment system.

\section{Conclusion and Limitations}

This research added a new research framework to an acceptance study of a dinar payment system in Malaysia, particularly in the study of the electronic dinar payment system. The framework for this research is adapted from UTAUT model with three new constructs added; to suitably explore 'intention to use' electronic dinar payment system. This study discovered that most of the respondents generally agree to accept the idea of using the proposed electronic dinar payment system. Apparently, it is found that certain factors are perceived to have stronger influence than the others. This is generally expected in any information system (IS) acceptance studies whereby different factors do exert different degree of influence on various constructs. The performance expectancy, facilitating conditions, perceived credibility, and attitude toward using carry the most weight (4.00 and above) among all constructs. It is expected that researchers and practitioners in dinar institutions would greatly benefit from this study. This result has given an early indication as to what would be the public's acceptance of dinar in the near future. Due to constraints on the length of the paper, the multiple linear regression analysis and the effects of moderating variables (age, gender, and experience) have not been examined in this descriptive analysis study. The multiple linear regression results have showed that performance expectancy, facilitating conditions, and attitude toward using are the dominant predictors of 'intention to use' electronic dinar payment system. The results of this multiple linear regression analysis will be taken up later in our future publications.

\section{References}

Barisheff, N. (2006). "August 15, 1971: Inflation Unleashed," [Online]. [Retrieved July 17, 2011], http://www.bmgbullion.com/document/3 16

Compeau, D. R. \& Higgins, C. A. (1995). "Computer Self-Eficacy: Development of a Measure and Initial Test," MIS Quaterly, 19 (2). 189-211.

Davis, F. D. (1989). "Perceived Usefulness, Perceived Ease of Use, and User Acceptance of Information Technology," MIS Quarterly, $13,319-340$.

Ha, S. \& Stoel, L. (2009). "Consumer eShopping Acceptance: Antecedents in Technology Acceptance Model," Journal of Business Research, 62 (2009). 565-571.

Kim, C., Tao, W., Shin, N. \& Kim, K.-S. (2010). 'An Empirical Study of Customers' Perceptions of Security and Trust in ePayment System," Electronic Commerce Research and Applications, 9 (2010). 84-95.

Kitco Inc. (2011). "Past Historical London Fix," [Online]. [Retreived July 17, 2011], http://www.kitco.com/gold.london fix.html

Leeb, S. \& Strathy, G. C. (2006). The Coming Economic Collapse: How You Can Thrive When Oil Costs $\$ 200$ a Barrel, Warner Business Books, New York. 
Lewis, N. K. (2007). Gold, the Once and Future Money, John Wiley \& Sons, Hoboken, New Jersey.

Meera, A.K.M. (2002). "The Islamic Gold Dinar," Pelanduk Publication, Selangor, Malaysia.

Paarlberg, D. (1993). An Analysis and History of Inflation, Praeger Publishers, Westport, Connecticut.

Pavlou, P. A. \& Gefen, D. (2004). "Building Effective Online Marketplaces with Institution-Based Trust," Information Systems Research, 15 (1). 37-59.

Schierz, P. G., Schilke, O. \& Wirtz, B. W. (2010). "Understanding Consumer Acceptance of Mobile Payment Services: An Empirical Analysis," Electronic Commerce Research and Applications, 9 (2010). 209216.

Shin, D.-H. (2009). "Towards an Understanding of the Consumer Acceptance of Mobile Wallet," Computers in Human Behavior, 25 (2009). 1343-1354.

Taylor, S. \& Todd, P. A. (1995). "Understanding Information Technology Usage: A Test of Competing Models,"
Information System Research, 6 (2). 144176.

Turk, J. \& Rubino, J. (2004). 'The Coming Collapse of The Dollar and How to Profit From It,' Currency Doubleday (Division of Random House Inc.). United States of America.

Venkatesh, V., Morris M. G., Davis, G. B. \& Davis, F. D. (2003). "User Acceptance of Information Technology: Toward a Unified View," MIS Quarterly, 27 (3). 425-478.

Wang, Y.-S., Wang, Y.-M., Lin, H.-H. \& Tang, T.-I. (2003). "Determinants of User Acceptance of Internet Banking: An Empirical Study," International Journal of Service Industry Management, 14 (5). 501519.

Yuen, Y. Y., Yeow, P. H. P, Lim, N. \& Saylani, N. (2010). "Internet Banking Adoption: Comparing Developed and Developing Countries," Journal of Computer Information Systems, 51 (1). 52-61.

Zhou, T, Lu, Y. \& Wang, B. (2010). "Integrating TTF and UTAUT to Explain Mobile Banking User Adoption," Computers in Human Behavior, 26 (2010). 760-767. 